\title{
The Effect of the Implementation of the Education on the Knowledge and Status of Dental Cleanliness in Elderly in Darul Imarah Aceh Besar District, Indonesia
}

\author{
Intan Liana ${ }^{1 *}$, Arnela Nur ${ }^{1}$, Anwar Arbi $^{2}$, Andriani Andriani ${ }^{1}$, Sisca Mardelita ${ }^{1}$, Elfi Zahara ${ }^{1}$, Cut Ratna Keumala ${ }^{1}$ \\ ${ }^{1}$ Department of Dental Nursing, Polytechnic of Health, Ministry of Health, Aceh, 23231, Indonesia; ${ }^{2}$ Faculty of Public Health, \\ University Muhammadiyah Aceh, Aceh, Indonesia
}

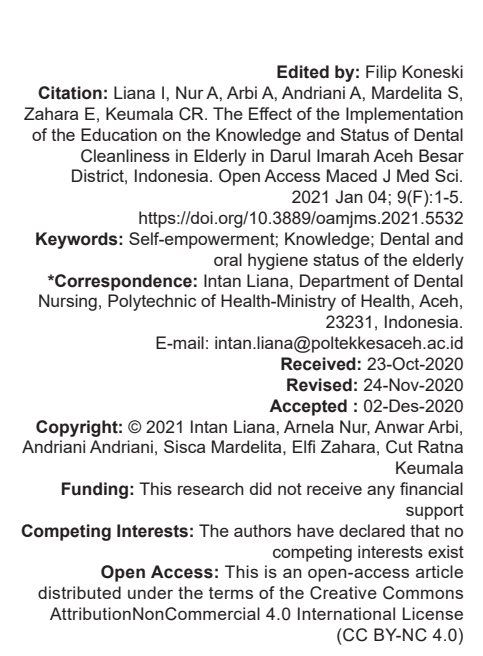

\section{Introduction}

Increasing the number of older adults is an indicator of development success and a challenge in development. Oral health has received global attention because it is closely related to general health and quality of life [1]. Over the age of 65 has more than doubled the world's total population during the period 1996-2020. In 2020, Indonesia's estimated elderly population will reach 28.8 million or $11.34 \%$, with a $\mathrm{UHH}$ of around 71.1 years [2]. It is estimated that the population aged 65 or over and 80 or over will increase to 29.2 and $39 \%$, respectively, by 2050 [3]. As the number of older adults in Indonesia increases, the attention that must be paid to this group will also be even more significant. The elderly are very dependent on care, declining health, and less attention [4]. Epidemiological data regarding the oral health of the elderly are scarce or absent [5].

Aging is a complex biological phenomenon that results from the interaction between genetic and environmental factors. This process can directly or indirectly increase the risk of developing the disease [6]. As the global population increases, health services for the elderly have been further developed to improve their health and quality of life [7], [8]. The increasing number of the elderly requires serious handling because they naturally experience physical, biological, and mental decline. Aging is a complex biological phenomenon that results from the interaction between genetic and environmental factors. This process can directly or indirectly increase the risk of developing the disease [6]. Nutrient deficiency represents a potential health threat to the entire elderly population [9]. Dental and oral health in the elderly is essential because it is closely related to general health. Oral health problems affect appearance, quality of life: and nutritional intake [10].

Oral health is one that must be considered. Overcome this problem needs necessary to optimize the ability of the elderly in maintaining oral hygiene through the provision of information and skills. Moreover, they are controlling risk through mastication. 
The number of people aged in the elderly category in the District of Darul Imarah amounted to 80 people. Based on the examination results on ten older people, the average dental and oral hygiene status were 5.6 with a wrong category, and empowerment needs to be done to maintain dental and oral hygiene for the elderly. This study aimed to analyze the effect of the selfempowerment package on the level of knowledge and dental and oral hygiene status in the elderly in Darul Imarah district, Aceh Besar, Indonesia.

\section{Methods}

This study used a quasi-experimental design with a pretest-posttest design with a control group design. This research was conducted in Darul Imarah District, Aceh Besar District. Subjects in this study were the elderly, namely 135 people, while those aged 60-70 years totaled 80 people. The research subjects were divided into two treatment groups: (1) The treatment group (I) was elderly people who lived in Kandang Village, Tingkeum Village, and Daroy Kameu Village, totaling 40 people, given dental health education based on self-empowerment and (2) The control group (II) is the elderly who live in Lheu Blang Village, Lamsiteh Village, and Lambung Village, totaling 40 people, who were not given intervention. The instrument for dental and oral hygiene checks used diagnostic sets, and the Oral Hygiene Index-Simplified (OHIS) index for the elderly is divided into two groups. Confounding factors for each group were determined, namely, gender, age, and education level. The analysis of the results of this study used: (1) Paired samples t-test, to determine the differences in increasing knowledge and oral hygiene status in the intervention group and the control group, namely from pre-test to post-test I, post-test I to posttest II, and pre-test to post-test II, (2). The independent t-test is to determine the difference in the increase in the two groups, and (3). Multivariate using the manova test.

\section{Results}

\section{Characteristics of research subjects}

The characteristics of research subjects in this study include age, gender, and education

Based on Table 1, the most dominant respondents' age was 60-61 years in the intervention group, $45 \%$ in the control group, $30 \%$. The female sex is prevalent, both in the intervention group and the control group. While the education level in the intervention group, $52.5 \%$ had an elementary level of education,
Table 1: Distribution of respondents by age, gender, and education in Groups I and II

\begin{tabular}{|c|c|c|c|c|}
\hline \multirow{2}{*}{$\begin{array}{l}\text { Characteristic respondent } \\
\text { Age }\end{array}$} & \multicolumn{2}{|c|}{ Group I } & \multicolumn{2}{|c|}{ Group II } \\
\hline & $\mathrm{n}$ & $\%$ & $\mathrm{n}$ & $\%$ \\
\hline $60-61$ & 18 & 45 & 12 & 30 \\
\hline $62-63$ & 8 & 20 & 10 & 25 \\
\hline $64-65$ & 8 & 20 & 7 & 17.5 \\
\hline $66-67$ & 1 & 2.5 & 8 & 20 \\
\hline $68-69$ & 2 & 5 & 2 & 5 \\
\hline $70-71$ & 3 & 7.5 & 1 & 2.5 \\
\hline Total & 40 & 45 & 12 & 30 \\
\hline \multicolumn{5}{|l|}{ Gender } \\
\hline Male & 8 & 20 & 3 & 7.5 \\
\hline Female & 32 & 80 & 37 & 92.5 \\
\hline Total & 40 & 100 & 40 & 100 \\
\hline \multicolumn{5}{|l|}{ Education } \\
\hline BS & 21 & 52.5 & 9 & 22.5 \\
\hline JHS & 15 & 37.5 & 19 & 47.5 \\
\hline SHS & 4 & 10 & 12 & 30 \\
\hline Total & 40 & 100 & 40 & 100 \\
\hline
\end{tabular}

$47.5 \%$ had a junior high school education level in the control group.

\section{Univariate analysis}

The univariate analysis in this study included: (1) Knowledge and status of dental and oral hygiene before treatment (pre-test) and after treatment (posttest I and post-test II).

Based on Table 2, the results of knowledge in the intervention group are $55 \%$ in the low category, while the control group is $57.5 \%$ in the high class. While respondents in the intervention group's oral hygiene status, $52.5 \%$ had a lousy category of dental and oral hygiene, while $62.5 \%$ of the control group was in the wrong class.

Table 2: Distribution of respondents based on knowledge, and dental and oral hygiene status in groups I and II before treatment

\begin{tabular}{|c|c|c|c|c|}
\hline \multirow{2}{*}{$\begin{array}{l}\text { Pre-test } \\
\text { Knowledge }\end{array}$} & \multicolumn{2}{|c|}{ Group I } & \multicolumn{2}{|c|}{ Group II } \\
\hline & $\mathrm{n}$ & $\%$ & $\mathrm{n}$ & $\%$ \\
\hline High & 18 & 45 & 23 & 57.5 \\
\hline Low & 22 & 55 & 17 & 42.5 \\
\hline Total & 40 & 100 & 40 & 100 \\
\hline \multicolumn{5}{|l|}{ Status OHIS } \\
\hline Good & 0 & 0 & 1 & 2.5 \\
\hline Middle & 19 & 47.5 & 14 & 35 \\
\hline Bad & 21 & 52.5 & 25 & 62.5 \\
\hline Total & 40 & 100 & 40 & 100 \\
\hline
\end{tabular}

Based on Table 3, the results of knowledge in the intervention group are $55 \%$ in the high category, while the control group is $65 \%$ in the low category. While the dental and oral hygiene status of respondents in the intervention group, $57.5 \%$ had a lousy category of dental and oral hygiene, while $52.5 \%$ of the control group was in the moderate category.

Table 3: Distribution of respondents based on knowledge, and dental and oral hygiene status in groups I and II after treatment

\begin{tabular}{|c|c|c|c|c|}
\hline \multirow{2}{*}{$\begin{array}{l}\text { Post-test } \\
\text { Knowledge }\end{array}$} & \multicolumn{2}{|c|}{ Groups I } & \multicolumn{2}{|c|}{ Groups II } \\
\hline & $\mathrm{n}$ & $\%$ & $\mathrm{n}$ & $\%$ \\
\hline High & 22 & 55 & 14 & 35 \\
\hline Low & 18 & 45 & 26 & 65 \\
\hline Total & 40 & 100 & 40 & 100 \\
\hline \multicolumn{5}{|l|}{ Status OHIS } \\
\hline Good & 0 & 0 & 0 & 0 \\
\hline Medium & 17 & 42.5 & 21 & 52.5 \\
\hline bad & 23 & 57.5 & 19 & 47.5 \\
\hline Total & 40 & 100 & 40 & 100 \\
\hline
\end{tabular}




\section{Testing prerequisite analysis}

Data analysis in this study used parametric statistics with t-test techniques (paired t-test), t-test (independent t-test), and MANOVA test. This study's data normality test used the Kolmogorov-Smirnov Z test and the $F$ test (Levene's test for equality of variances). Tests were carried out with computer software, Statistic Program for the Social Science (SPSS) version 16. The results of the normality and homogeneity test are as follows:

The results of testing with the KolmogorovSmirnov Z test, and Levene's test for equality of variances, were all significant at the $5 \%$ significance level $(p>0.05)$, which means that the data in this study were normally distributed and homogeneous (Table 4).

Table 4: Analysis of Results Normality and Homogeneity Tests of Data Distribution at Group I and Group II

\begin{tabular}{llll}
\hline Data distribution variable & \multicolumn{2}{l}{ Kolmogorov-Smirnov } & Conclusion \\
\cline { 2 - 3 } & $\mathrm{Z}$ & $\mathrm{p}$ (sig.) & \\
\hline Knowledge & 1.346 & 0.053 & Normal \\
Cleanness of teeth and mouth & 1.190 & 0.118 & Normal \\
\hline & \multicolumn{2}{l}{ Levene's test for equality of variance } \\
\cline { 2 - 4 } & F. hit & $\mathrm{p}$ (sig.) & \\
\hline Knowledge & 0.221 & 0.639 & Homogen \\
Cleanness of teeth and mouth & 1.312 & 0.254 & Homogen \\
\hline
\end{tabular}

\section{Analysis (paired sample t-test)}

The results of the analysis of the mean increase in knowledge and oral hygiene status of respondents from pre-test to post-test I, from post-test I to post-test II, and from pre-test to post-test II in treatment groups I and II, as follows.

The results showed no difference in knowledge in the control group in the post-test I and post-test 2 with a value of $p=0.72$, and there was a difference in knowledge in the intervention group in the post-test $\mathrm{I}$ and post-test 2 with a value of $p=0.002$. Based on the results of the study, it was found that there were differences in oral hygiene in the control group, and there were differences in dental and oral hygiene after being given the intervention with a value of $p=$ 0.003 . There was a difference in the mean knowledge from post-test post-test I to post-test post-test II $(\mathrm{p}=$ $0.002)$. There was a difference in this status from pretest to post-test $1(p=0.003)$. Whereas in group II, there was no difference in the mean knowledge from pre-test to post-test I and from post-test I to post-test II (Table 5).

Table 5: Analysis of Mean Knowledge and Status of Respondents' Oral and Dental Hygiene from Pre-test to Posttest I, and from Post-test I to Post-test II, in the Treatment Group and the Control Group

\begin{tabular}{|c|c|c|c|c|c|c|}
\hline \multirow{2}{*}{$\begin{array}{l}\text { Variable } \\
\text { Knowledge }\end{array}$} & \multicolumn{3}{|l|}{ Group I } & \multicolumn{3}{|l|}{ Group II } \\
\hline & Average \pm SD & $\mathrm{Cl}$ & $\mathrm{P}$ & Average \pm SD & $\mathrm{Cl}$ & $\mathrm{P}$ \\
\hline Pre-test & $6.28 \pm 0.78$ & $0.15-0.31$ & 0.35 & $5.78 \pm 1.31$ & $0.15-0.31$ & 0.35 \\
\hline Post-test 1 & $6.55 \pm 0.59$ & & & $5.68 \pm 1.6$ & & \\
\hline Post-test 1 & $6.55 \pm 0.59$ & $0.84-3.28$ & $0.002^{*}$ & $5.68 \pm 1.31$ & $0.50-0.35$ & 0.72 \\
\hline Post-test 2 & $6.03 \pm 1.00$ & & & $5.75 \pm 0.70$ & & \\
\hline \multicolumn{7}{|l|}{ Status OHIS } \\
\hline Pre-test & $3.77 \pm 1.14$ & $0.11-0.52$ & $0.003^{*}$ & $3.68 \pm 0.99$ & $0.06-0.47$ & $0.01^{*}$ \\
\hline Post-test 1 & $3.45 \pm 0.80$ & & & $3.60 \pm 0.76$ & & \\
\hline Post-test 1 & $3.45 \pm 0.80$ & $0.02-0.19$ & 0.11 & $3.45 \pm 0.80$ & $0.41-0.09$ & $0.03^{*}$ \\
\hline Post-test 2 & $3.37 \pm 0.65$ & & & $3.37 \pm 0.63$ & & \\
\hline
\end{tabular}

\section{Analysis (independent t-test)}

Based on Table 6 shows that there are differences in the level of knowledge and status of dental and oral hygiene after self-empowerment-based education in the elderly $(p<0.05)$. Statistically, it can be seen that there is an effect of the education package on the dental and oral hygiene status of the elderly $p<0.05$, but practically the OHIS value of the elderly from post 1 to post 2 is not much different.

Table 6: Average knowledge and status of respondents teeth and oral hygiene before and after being given selfempowerment-based education to the elderly in the Darul Imarah district of Aceh Besar

\begin{tabular}{llll}
\hline Variable & Average \pm SD & $\mathrm{Cl}$ & $\mathrm{p}$ \\
\hline Education knowledge & $5.73 \pm 1.15$ & $0.80-0.29$ & $0.001^{*}$ \\
& $6.28 \pm 0.83$ & & \\
Education-status OHIS & $3.77 \pm 0.83$ & $0.02-0.46$ & $0.03^{*}$ \\
& $3.53 \pm 0.89$ & & \\
\hline
\end{tabular}

\section{Multivariate analysis}

In this study, the MANOVA test was used to determine the effect of self-empowerment based education on the elderly on knowledge and status of oral and dental hygiene. The homogeneity test results with the levels test of equality of error variances in the knowledge group and this status were the same as the value of $p>0.05$. Based on the results of the multivariate significance test, the $F$ value of education at Pillai's Trace, Wilks' Lambda, Hotelling's Trace, and Roy's Largest Root has a value of $p=0.001$, and this indicates that there is an effect of self-empowermentbased education in the elderly on knowledge and status of oral and dental hygiene. Then, the results of the MANOVA test are as follows:

Based on Table 7, it shows that statistically, education has more influence on knowledge, $p<0.05$.

Table 7: The effect of self-empowerment-based education on the knowledge and status of respondents' dental and oral hygiene in the elderly community in the Darul Imarah district of Aceh Besar

\begin{tabular}{lcc}
\hline Variable & F & Sig. \\
\hline Education & 10.4 & $0.001^{*}$ \\
$\quad$ Pillai's Trace & & \\
Wilks' Lambda & & \\
Hotelling's Trace & & \\
Roy's Largest Root & 17.8 & $0.001^{*}$ \\
Knowledge & 4.64 & $0.03^{*}$ \\
Status OHIS & & \\
\hline
\end{tabular}

\section{Discussion}

The results showed a significant effect of giving a self-empowerment-based educational package to the elderly on the level of knowledge and status of dental and oral hygiene $(p<0.05)$. Based on multivariate analysis, the knowledge, attitude, and behavior variables toward maintaining dental and oral hygiene had a significant 
effect on pre-elderly people's periodontal health status $(p=0.001)$. That there were differences in the level of knowledge and dental and oral hygiene status after selfempowerment-based education in the elderly $(p<0.05)$. The education provided to the elderly can provide knowledge about the importance of maintaining oral health and the risks experienced if oral health is ignored. The Oral Health Education Program is closely related to the awareness and income of elderly families [11]. It is hoped that the awareness arising from the elderly can foster a tendency to manifest it in action so that the elderly can independently maintain dental and oral health, which will significantly affect the quality of life of the elderly. Oral health education programs targeting caregivers may be an effective strategy for improving oral hygiene [12]. Oral health is now considered to be as important as general health, with growing evidence showing a link between systemic health and major diseases such as cardiovascular disease, diabetes, obesity, arthritis, mild cognitive impairment, and even cancer [13], [14]. Attitudes and actions to maintain oral hygiene can also affect a person's behavior toward oral hygiene. Some elderly have good knowledge about the importance of oral hygiene but have low oral hygiene status. it may be due to a person's negative attitude in absorbing knowledge obtained but not applying it in daily actions and behavior. Improving nurses' oral health attitudes need dental education and training programs to be given high priority [15]. The results showed no difference in knowledge in the control group in the posttest I and post-test 2 with a value of $p=0.72$, and there was a difference in knowledge. There was a difference in knowledge In the post-test intervention group, I and post-test 2 with a value of $p=0.002$. Researchers assume that the elderly's knowledge increases because the elderly have gained knowledge and interest that has arisen so that there is a desire to seek additional information about oral health from various sources. Poor oral health and impaired cognition negatively impact health and cognitive decline through specific biological mechanisms. Daily oral hygiene is critical to prevent oral diseases such as caries or periodontal disease [16]. Poor oral health and cognitive impairment suggest that cognitive decline can negatively impact oral health and that poor oral health can lead to cognitive decline through specific biological mechanisms [17]. As a result, a decrease in oral health conditions in the elderly, such as dental caries and periodontal disease, is expected [18]. In the intervention activity, the elderly is also provided with a manual for maintaining oral dental health that the elderly can review the information that has been given. Statistically, it can be seen that there is an effect of the education package on the dental and oral hygiene status of the elderly $p<0.05$, but practically the OHIS value of the elderly from post 1 to post 2 is not much different. The elderly have bad habits in maintaining oral and dental hygiene, such as inappropriate frequency and time of brushing their teeth, incorrect brushing techniques. Lack of attention to oral care is a hidden health hazard because dental awareness and oral health are considered important for general health and quality of life [19]. The statistical test results showed that there was an effect of selfempowerment-based education on the knowledge of the elderly, $p=0.001$. The author assumes that this happens because the elderly have received oral health maintenance information from the interventions given in education about oral health. Education is provided to increase the elderly's knowledge so that it is hoped that it can be manifested independently in their daily behavior. Family support plays a critical role in encouraging the interest or willingness of the elderly in maintaining dental and oral health. Family can be a strong motivator for the elderly to accompany, remind, and guide the elderly if they forget to brush their teeth, and help overcome all the elderly's problems.

\section{Conclusion}

There is a significant effect of providing selfempowerment-based education packages to the elderly on the level of knowledge and dental and oral hygiene status.

\section{References}

1. World Health Organization Oral Health. 2019.

2. Direktorat Pelayanan Sosial lanjut Usia Kemensos RI. Pedoman Pemberian Bantuan Sosial Bagi LKS Lanjut Usia. Jakarta: Direktorat Pelayanan Sosial lanjut Usia Kemensos RI; 2012. https://doi.org/10.31595/peksos.v16i1.98

3. PetelinM, CotičJ,PerkičK, PavličA. Oralhealth oftheelderlylivingin residential homes in Slovenia. Gerodontology. 2012;29(2):e44757. https://doi.org/10.1111/j.1741-2358.2011.00497.x PMid:21615469

4. Panchbhai AS. Oral health care needs in the dependant elderly in India. Indian J Palliat Care. 2012;18(1):19-26. https://doi. org/10.4103/0973-1075.97344 PMid:22837606

5. De Lima Saintrain MV, Gonçalves RD. Salivary tests associated with elderly people's oral health. Gerodontology. 2013;30(2):917. https://doi.org/10.1111/j.1741-2358.2012.00627. PMid:23379591

6. Glazar I, Urek MM, Brumini G, Pezelj-Ribaric S. Oral sensoria complaints, salivary flow rate and mucosal lesions in the institutionalized elderly. J Oral Rehabil. 2010;37(2):93-9. https:// doi.org/10.1111/j.1365-2842.2009.02027.x

PMid:19968768

7. de Oliveira TC, da Silva DA, Leite de Freitas YN, da Silva RL, Pegado CP, de Lima KC. Socio-demographic factors and oral health conditions in the elderly: A population-based study. Arch Gerontol Geriatr. 2013;57(3):389-97. https://doi.org/10.1016/j. archger.2013.05.004

PMid:23773366 
8. Tsakos G. Inequalities in oral health of the elderly: Rising to the public health challenge? J Dent Res. 2011;90(6):689-90. https:// doi.org/10.1177/0022034511407072

\section{PMid:21508434}

9. Sharkey JR, Haines PS. Nutrition risk screening of homedelivered meal participants: Relation of individual risk factors to functional status. J Nutr Elder. 2002;22:15-34. https://doi. org/10.1300/j052v22n01_02

10. Blaggana A, Grover V, Kapoor A, Blaggana V, Tanwar R, et al. Oral health knowledge, attitudes and practice behaviour among secondary school children in Chandigarh. J Clin Diagn Res. 2016;10(10):ZC01-6. https://doi.org/10.7860/ jcdr/2016/23640.8633 PMid:27891447

11. Guzman E, Hiatt RA. Effectiveness evaluation of contra caries oral health education program for improving Spanish-speaking parents' preventive oral health knowledge and behaviors for their young children. Community Dent Oral Epidemiol. 2016;44(6):564-76. https://doi.org/10.1111/cdoe.12250 PMid:27517458

12. Manchery N, Subbiah GK, Nagappan N, Premnath P. Are oral health education for carers effective in the oral hygiene management of elderly with dementia? A systematic review. Dent Res J (Isfahan). 2020;17(1):1-9. https://doi. org/10.4103/1735-3327.276232 PMid:32055287

13. Linden GJ, Lyons A, Scannapieco FA. Periodontal systemic associations: Review of the evidence. J Periodontol. 2013;84(4):S8-19. https://doi.org/10.1111/jcpe.12064 PMid:23631586

14. Taylor JJ, Preshaw PM, Lalla E. A review of the evidence for pathogenic mechanisms that may link periodontitis and diabetes. J Periodontol. 2013;84(4):S113-34. https://doi.org/10.1111/ jcpe.12059

PMid:23631573

15. Shah AH, Naseem M, Khan MS, Asiri FY, AIQarni I, Gulzar S, et al. Oral health knowledge and attitude among caregivers of special needs patients at a comprehensive rehabilitation centre: An analytical study. Ann Stomatol (Roma). 2018;8(3):110-6. https://doi.org/10.11138/ads/2017.8.3.110 PMid:29682223

16. Gil-Montoya JA, Sánchez-Lara I, Carnero-Pardo C, FornielesRubio F, Montes J, Barrios R, et al. Oral hygiene in the elderly with different degrees of cognitive impairment and dementia. J Am Geriatr Soc. 2017;65(3):642-7. https://doi.org/10.1111/ jgs. 14697 PMid:28024093

17. Nangle MR, Riches J, Grainger SA, Manchery N, Sachdev PS Henry JD. Oral health and cognitive function in older adults: A systematic review. Gerontology. 2019;65(6):659-72. https://doi. org/10.1159/000496730 PMid:30904915

18. López R, Smith PC, Göstemeyer G, Schwendicke F. Ageing dental caries and periodontal diseases. J Clin Periodontol. 2017;44(18):S145-52. https://doi.org/10.1111/jcpe.12683 PMid:28266118

19. Somma F, Castagnola R, Bollino D, Marigo L. Oral inflammatory process and general health. Part 1: The focal infection and the oral inflammatory lesion. Eur Rev Med Pharmacol Sci. 2010;14(12):1085-95.

PMid:21375141 